\title{
SPORT AS THE BASIC CONTENTS OF LEISURE IN BIODROMAL PERSPECTIVE. AN EXAMPLE OF LONG-DISTANCE RUNNERS
}

\author{
Miloš Bednářr , Romualdas Malinauskas ${ }^{2}$ \\ Charles University in Praguel, Czech Republic \\ Lithuanian Sports University', Lithuania
}

\begin{abstract}
Background. The study analyses sport as the basic contents of leisure in biodromal perspective ad the ascetic lifestyle of an athlete. Ascetic lifestyle is observed not only as it contributes to the best performances, but also to lifelong participation including, for instance, long-distance runners with the stage of minimally 20 years of competition racing. The latter is the centre of our attention. The object of the research is sport as the basic contents of leisure in biodromal perspective. Research aim is to analyse the ascetic lifestyle of an athlete; to map the real role of asceticism in the sports sphere on example of long-distance runners.

Methods. We researched a special group of long-distance runners with the stage of minimally 20 years of competition racing (168 athletes). A research questionnaire with this special group was implemented. Descriptive statistical evaluation was performed.

Results. We found noticeable ascetic features of lifestyle among long-distance runners with the stage of minimally 20 years of competition racing. They exercise (it is an original meaning of the Greek word askésis) both body and will in lifelong horizon. They know that running (which is higher level of jogging) is also joined with some portion of pain and they are ready to sign a specific runners' motto: "Pain is inevitable. Suffering is optional." If the option is "suffering", the situations open the way to peak experiences.

Conclusion. Promoting "reasonable asceticism" can be one aspect of raison d'être of today's sport in this postmodern world with the supremacy of hedonistic orientation.
\end{abstract}

Keywords: leisure, running, lifestyle, motivation, asceticism.

\section{INTRODUCTION}

$\mathrm{S}$ port can be not only an enjoyable hobby, but also a firm linchpin of leisure. Can it hold true in biodromal (lifelong) perspective? What a big part of leisure can sports take? What is the relation between sports and lifestyle?

We followed a group of long-distance runners with the stage of minimally 20 years of competition racing. They were "tested" on the traditional $10 \mathrm{~K}$ running race called "Běchovice" (small village near Prague) during many years. The race was founded in 1897 and has been hosted each year without break - at 117 years it is the oldest road race on the Continent. Each runner from that special group was able to participate in this race minimally 20 times. The route is very hilly and it is not possible to run it without good previous training.

We were interested in aspects of motivation to continue running for a long time and especially the role of tradition in it.

Scientific novelty: the present research will provide the first thorough analysis of long-distance runners with the stage of minimally 20 years of competition racing.

The object of the research was sport as the basic contents of leisure in biodromal perspective.

The aim of the research was to analyse an ascetic lifestyle of athlete, to map the real role of 
asceticism in the sports sphere on the example of long-distance runners.

\section{METHODS}

We researched a special group of longdistance runners with the stage of minimally 20 years of competition racing (168 athletes). A questionnaire survey with this special group was implemented. Descriptive statistical evaluation was performed.

\section{RESULTS}

The role of tradition. There is an imperative of permanent innovation in topical management. We can see forced effort of running races organizers to change the route or distance each year. In "Běchovice" we can see an opposite approach, using the power of tradition - the route is the same from 1911 and we can compare the best results and each runner can compare their own personal results in the lifelong perspective. Here lies the perfect area of comparisons of different types for statisticians. One example: we are able to find the best performances not only at absolute scale, but even year by year during the whole history of the race (Figure 1).

Comparison of the results of males and females is presented in the Figure 2.

Aforementioned constancy of the route is only one aspect of tradition - it is also formed with

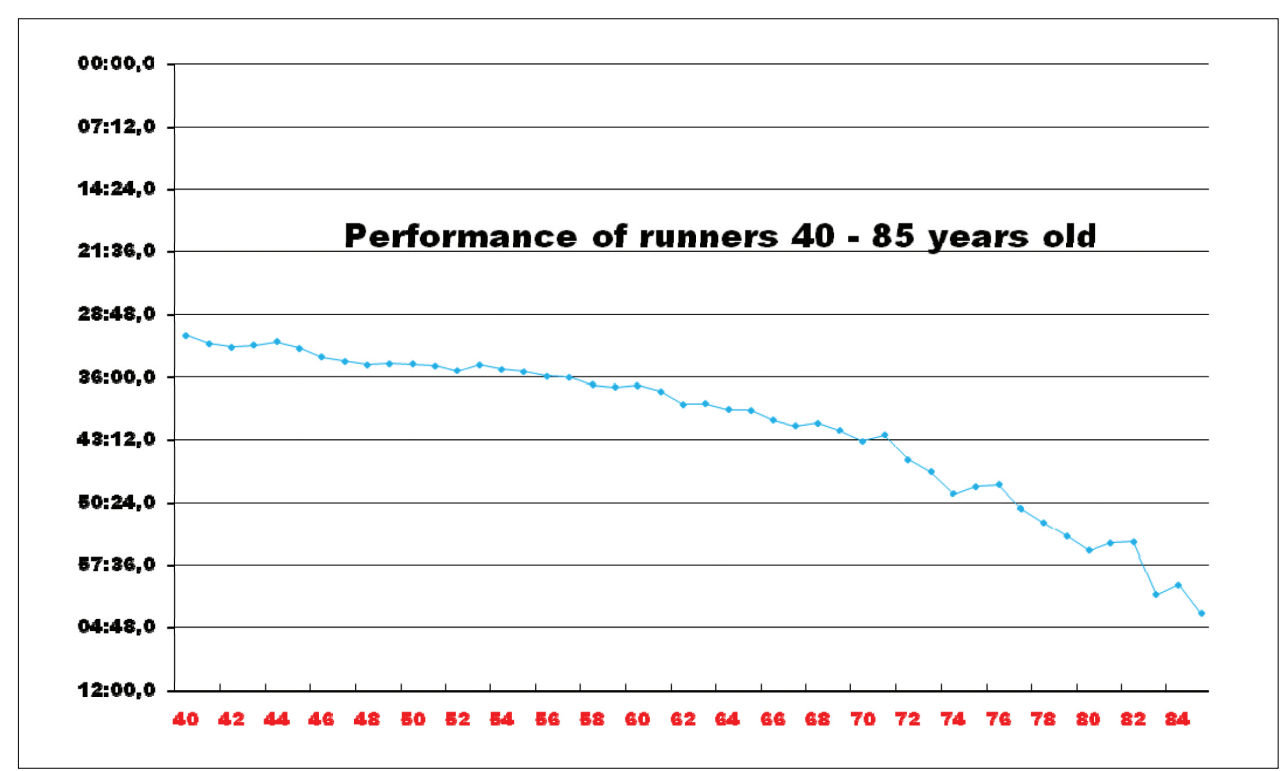

Figure 1. Performance of 40-85-year-old runners (min, s)

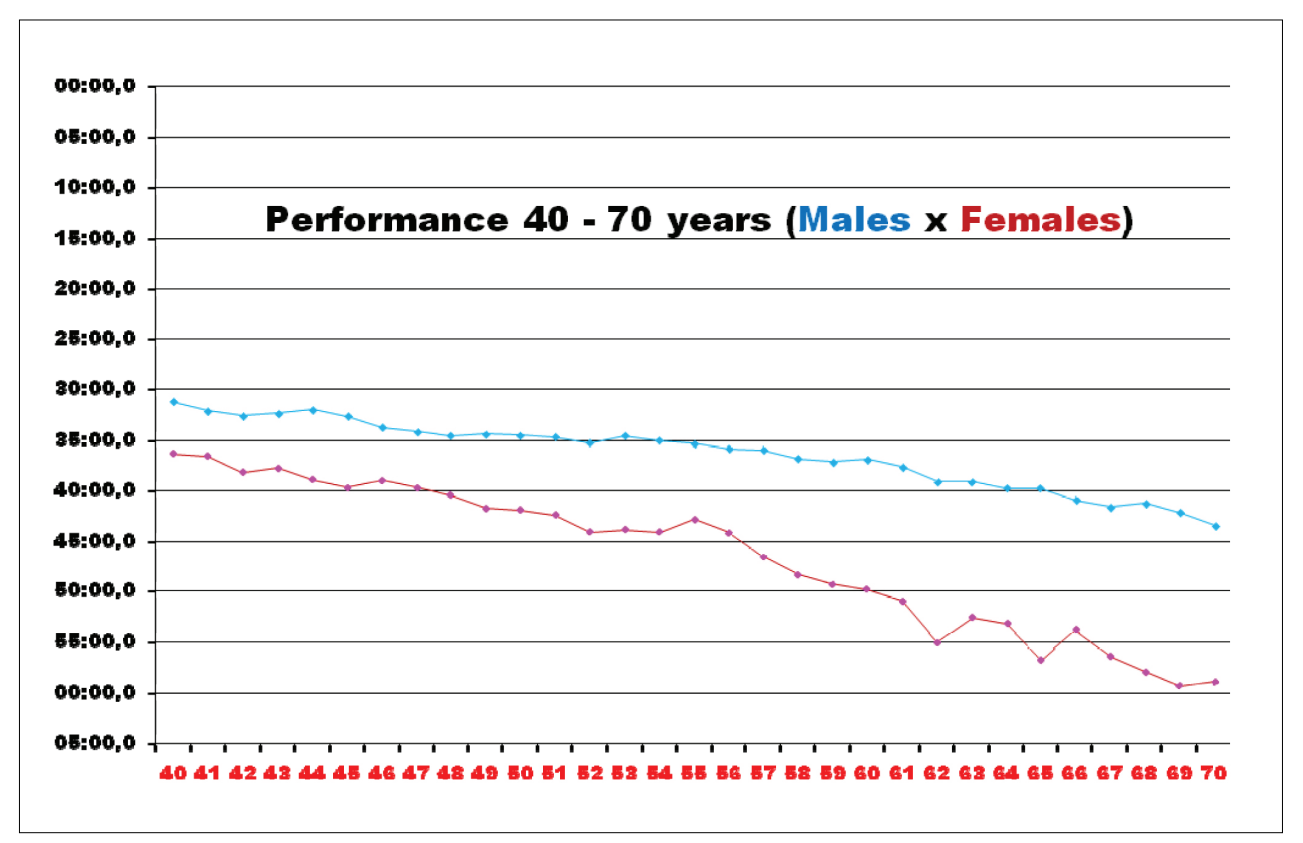

Figure 2. Performance of 40-70-year-old male and female runners (min, s) 
Figure 3. Numbers of runners in the traditional $10 \mathrm{~K}$ running race called "Běchovice" till 2009

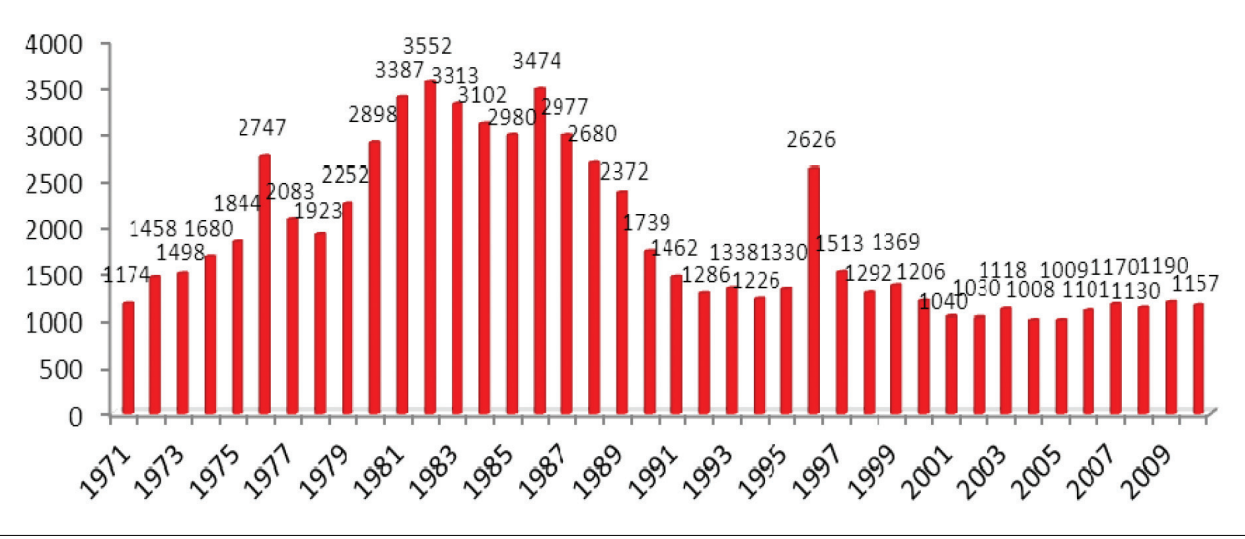

duration (not only 117 years, but non-stop tradition without break even during both World Wars), number of attenders (max. 3552 in 1982), interest of media, "brand awareness", etc.

We can speak about a "big" tradition, the tradition of the race itself. Yet we mean, there is a "small" tradition as well, tradition of concrete persons, families or groups, with no less meaning. It is due to the personal loyalty to the race, engagement of the whole families or groups of athletes from one institution in tradition.

Twenty five years ago there was a critical situation with the number of runners (in clear relation with political changes in so called Eastern Block). The fall from "golden 80 's" was very sharp (Figure 3).

In effort to improve the situation, we began to publish different types of statistics to attract runners and draw them back. We promoted running in any age - in biodromal (lifelong) perspective. One can say for example: I am a record holder for the age of 73 years... and the like. Yet there are runners with lower performance - the list of so called "loyal" runners with minimally 20 participations was done just for them. The first brochure (1991) had only 23 names; today there are 297 of them (35 is after death) and 125 from them participated in the last race (September 2014). The top of the list is presented in Table 1.

Finally in 2011the first book about "Běchovice" was published (Bednár., 2011) and among a number of statistics there are also the ones with ranking of the best families (e.g. one with 118 participations of their members and two with four generations of runners), the best married couples, father and son, etc. Much attention was given to the participation of women.

Each year all data are updated just after finishing the race and published on web sites. The aim was clear - to raise motivation to run in the race. Looking at increasing numbers of runners during last years, we can judge that the effort was successful (Figure 4). Of course, there can also be other influences, but what is considerable (and can support our "hypothesis") is: the increase in number of participants is due to women and veterans! By the way, during the last years the number of veterans has been higher than the number of younger runners.

Motivation and lifestyle of runners. Research on exercise motivation is often grounded in Deci and Ryan's self-determination theory (SDT; Deci, Koestner, \& Ryan, 1999; Deci \& Ryan, 1985; Malinauskas, 2008; Malinauskas, Batutis, \& Jetkevičius, 2005). Attention is given to the fact that motivation has two sources - one flowing out of a person's inside (intrinsic) and the other coming from outside (extrinsic). Intrinsically motivated runners possess an intrinsic scheme that encourages them to be competent and to find their own way of solving and mastering a task, and to seek success. Competence, persistence, mastery and success are the goals that are pursued by intrinsically motivated runners and their achievements are a reward by itself. Extrinsic motivation comes from other people through positive and negative reinforcement (reinforcement means everything that increases or decreases the probability of the repetition of certain behaviour). It is thought that long-term maintenance of exercise behaviours (for instance, of running) depends more on intrinsic motivation (Gallagher \& Updegraff, 2011). Nonetheless, a common perspective is that intrinsic motivation alone cannot sustain a physically active lifestyle (Edmunds, Ntoumanis, \& Duda, 2006). Our research was concerned with how intrinsic and extrinsic motivations related to running might vary in biodromal perspective (across the lifespan). 


\begin{tabular}{|c|c|c|c|}
\hline $\begin{array}{c}\text { Number of } \\
\text { times }\end{array}$ & Name and surname & $\begin{array}{l}\text { Life years/ } \\
\text { *Birth years }\end{array}$ & $\begin{array}{l}\text { Interval between the first } \\
\text { and the last start }\end{array}$ \\
\hline 55 & KOČÍ Jaroslav & 1906-1999 & $1925-1994$ \\
\hline 55 & OTČENÁŠEK Luboš & $* 1935$ & $1958-2012$ \\
\hline 52 & KŘÍǏ Vladimír & $* 1943$ & $1963-2014$ \\
\hline 50 & TŘEŠŇÁK Jiří & $* 1930$ & $1956-2005$ \\
\hline 50 & PLEŠINGER Stanislav & *1938 & $1963-2014$ \\
\hline 49 & ŠIMON Miloš & $* 1944$ & $1966-2014$ \\
\hline 48 & HÁK Jaroslav & *1946 & $1965-2014$ \\
\hline 47 & DOLEČEK František & *1943 & 1966-2014 \\
\hline 46 & MLEJNEK Jaroslav & *1934 & $1960-2011$ \\
\hline 46 & STEHLÍK Oldřich & *1948 & 1966-2014 \\
\hline 44 & PAUL Josef & $1904-1986$ & $1924-1979$ \\
\hline 44 & KLIMPERA Jaroslav & *1936 & $1961-2010$ \\
\hline 44 & DOLEJŠ Jan & *1949 & $1971-2014$ \\
\hline 43 & LAJČÍK Alois & $* 1940$ & $1971-2014$ \\
\hline 43 & KAPLICKÝ Vincenc & *1949 & $1971-2014$ \\
\hline 43 & KAISLER František & $* 1940$ & $1967-2014$ \\
\hline 42 & ČTVRTEČKA Jan & $* 1941$ & $1963-2008$ \\
\hline 42 & KODYM Ladislav & $* 1938$ & 1960-2012 \\
\hline 42 & JANU゚ Luděk & $* 1954$ & 1973-2014 \\
\hline 42 & MATIÁŠEK Petr & *1946 & $1972-2014$ \\
\hline 42 & ROSSMANN Petr & *1946 & $1972-2014$ \\
\hline 42 & MÁLEK Jaroslav & *1946 & 1970-2014 \\
\hline 41 & JANKA Jiří & *1948 & $1974-2014$ \\
\hline 41 & BRŮŽEK Zdeněk & *1954 & $1972-2014$ \\
\hline 40 & ZAHÁLKA Pavel & $* 1943$ & 1969-2009 \\
\hline 40 & NOVÁK Pavel & *1953 & $1975-2014$ \\
\hline
\end{tabular}

Table 1. The top of the list of so called "loyal" runners with minimally 40 participations

Note. The right column shows the interval between the first and the last start.

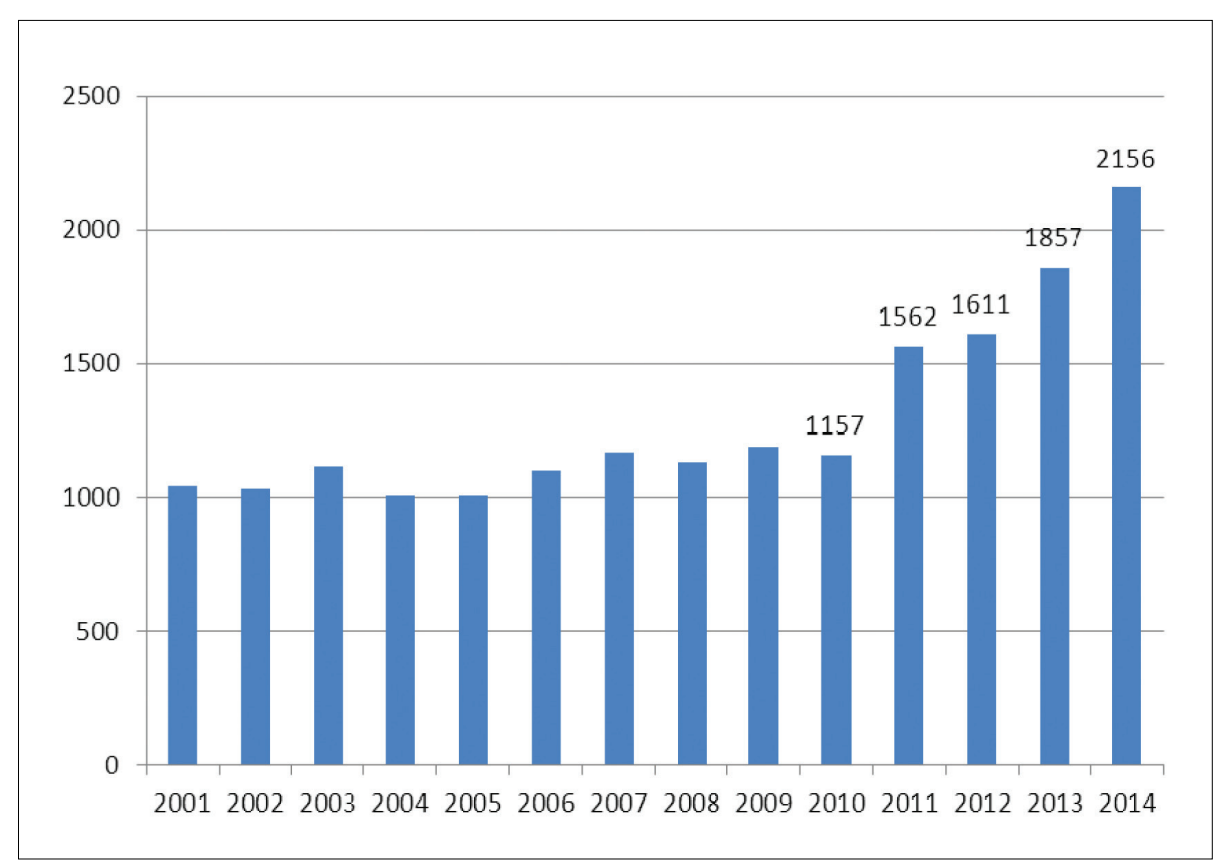

Figure 4. Number of runners in the traditional $10 \mathrm{~K}$ running race called "Běchovice" showing increase since 2011 
Considering motivation of runners, we implemented special research about it in connection with lifestyle in the mentioned group of runners with minimally 20 participations. 220 runners (including 7 women) received our questionnaire and 168 (76.36\%) answered (all women). The youngest was 38 and the oldest 93 years. Average age was 63.89 years.

Concerning motivation, we offered our respondents 10 possible motives for running and asked them to compare the motivation at the beginning of sports carrier and in the presence (it is evident that difference is minimally 20 years). They could choose more motives. Two "winning" motives were the same "earlier" and "now": 1) Running gives me the joy due to the optimal work of all bodily functions and "pleasant tiredness" with a relaxing state after training or race. 2) I like outdoor running and during it I enjoy to be a fighter against my indolence and vagaries of weather.

High position was held in the case of "appreciation that everything is result of my own efforts under the principles of fair play in running" (both "earlier" and "now"). Orientation on performance was detected - unsurprisingly "earlier" and lost its power in the late periods of run carriers (also unsurprisingly). The last position gained the motive with orientation on rise of selfconfidence through running (both "earlier" and "now").

Our runners could also add some other motives - and they were very creative in this. Set of the most interesting answers:

- "Run is for me a 'massage' of creativity and sometimes even enter to the spiritual area."

- "It is positive addiction and endorphins "hunting" for me."

- "It is a good testing of my will, leading to a personal discipline and strict time management balancing work, leisure and family duties."

- "Run is within easy reach - from spatial, time and social point of view."

- "Run is the best way of monitoring your weight."

The target group is formed from mature personalities. In running they are able to find actualization of many needs from famous Maslow's hierarchy ("pyramid") of needs (Maslow, 1954) - not only deficiency needs (D-needs), but also growth (or "being") needs (B-needs).

Comparing with a similar attitude to running, we can quote Japanese writer and marathon runner Haruki Murakami: "I run in order to acquire a void." It sounds like "high philosophy" of Buddhism, yet author explains that "human beings' emotions are not strong or consistent enough to sustain a vacuum. What I mean is the kinds of thoughts and ideas that invade my emotions as I run remain subordinate to that void. "Another thought: "I just run." (Murakami, 2009, p. 17). The last sentence is very close to the way of thinking of Forrest Gump from the movies of the same name: "I simply run...".

Some results, especially in long-distance running, look as if they are achieved without special ("ascetic") effort. We speak about situations from so called "zone". It is a special state of euphoria or easiness. It was described by Douillard (1994) in the field of sport and can be ranked among peak experiences (Csikszentmihalyi, 2009; Bednáŕ, 2009, 2011). Yet we are persuaded that state is not attainable without a previous period of "ascetic" training - it is hardly unattainable for "common" people. Many authors (Bednáŕ, 2009; Overman, 2011) warn about the close relation between sports and asceticism. We can find many cases of ascetic commitment among athletes of the four professional leagues in North America (baseball, basketball, football, ice hockey) as well: “. . dedicated athletes deny themselves sex, alcohol, tobacco, food, sleep, physical comfort, and other pleasures." (Overman, 2011, p. 171).

Other question aims to the number of years of participation in run races. It was obvious that the number must be higher than 20. Results are presented in Table 2. Average is 36.3 years. Fascinating - especially for laypersons - is the top of this ranking: $65-62-60-56$ years, etc.

Table 2. Number of years of participation in run races

\begin{tabular}{|l|l|l|l|l|}
\hline Number of years & $20-29$ & $30-39$ & $40-49$ & $>50$ \\
\hline Number of runners & 37 & 74 & 37 & 20 \\
\hline
\end{tabular}

Participation in races must be supported with good training - in running it is especially a question of the number of kilometres. We were 


\begin{tabular}{|l|c|c|c|c|c|c|}
\hline $\begin{array}{l}\text { Lifelong } \\
\text { kilometrage }\end{array}$ & $\begin{array}{c}\leq 20000 \\
\mathrm{~km}\end{array}$ & $\begin{array}{c}20001- \\
40000 \mathrm{~km}\end{array}$ & $\begin{array}{c}40001- \\
60000 \mathrm{~km}\end{array}$ & $\begin{array}{c}60001- \\
80000 \mathrm{~km}\end{array}$ & $\begin{array}{c}80001- \\
100000 \mathrm{~km}\end{array}$ & $\begin{array}{c}>100000 \\
\mathrm{~km}\end{array}$ \\
\hline $\begin{array}{l}\text { Number of } \\
\text { runners }\end{array}$ & 24 & 45 & 22 & 28 & 13 & 21 \\
\hline
\end{tabular}

Table 3. Number of

kilometres in the

lifelong horizon

interested in how many kilometres they have run in the lifelong horizon. They ought to estimate it (if possible), yet 38 of them were able to send precise number; 15 respondents said "sorry" so that we received information from 153 of them (Table 3).

Average is $58847 \mathrm{~km}$. Fascinating (again) is the top of this ranking: $380000 \mathrm{~km}($ !) $-238000 \mathrm{~km}-$ 203570 - $170000 \mathrm{~km}$ - 154505 - etc. The leader was able to have run it during 40 years (between his 17 and 57), which means $26 \mathrm{~km} /$ day... Do not forget that we are the country of Emil Zátopek and his giant kilometrage goes viral among his followers...

On the other side there are respondents with a low kilometrage. It corresponds to their orientation not only on running. Another question aimed to other sports they go in and it is not surprising that the aforementioned group prefers more sports and that among "pure" runners (50 respondents in lifelong horizon, it means $29.8 \%$ ) are these with high kilometrage. Which other sports are preferred? Cycling and ski running are leading; football is № 3 in youth, but it has been replaced by swimming. Some respondents are real all-round athletes with more than 5 done sports.

\section{DISCUSSION}

All mentioned bears witness about lifestyle and leisure contents of our special group. Other questions concerning profession and education, type of loyalty to "Běchovice" and relation to other races aimed - directly or indirectly - to a lifestyle. Respondents also had a lot of opportunities to add their own opinions and they used that plentifully. "Running is my lifestyle," sounded not only once. Or: "Running fulfils my leisure so that there is no boredom in my life." The last example: "Running is a good test of my will and helps me to stimulate the whole lifestyle." Can we doubt if run forms part of leisure of our respondents, or if their lifestyle is active?

It is obvious that so intensive engagement in running has influence on almost all aspects of lifestyle: leisure time activities, care of their own health, regimen, family life (including sexuality), working life. Yes, we know this influence can be not only positive: other leisure activities can be too reduced (e.g. there is no time or energy for cultural activities), too strong care of their own health can lead to hypochondria or egoism, a regimen can be too subordinated to running, family life can be disrupted; one elder (1981) similar research of Czech runners detected "higher irradiation of exhaustion on activities following a run", etc. Yet we do not find these negativities among our group: they speak about good feeling due to being fit, about the ability to arrange optimal time management, about support of their families, and instead of "irradiation of exhaustion" they speak about "pleasant exhaustion" and good start into a working day (if training is in the morning). They are active (and successful) in the other life activities as well: there is a former minister, well-known heart surgeon and astronomer, some university professors, etc. among our group members. We are sure the benefits of running exceed the losses, and our respondents would agree. As usual in our lives, we must know our limits and find balance in our activities.

We found noticeable ascetic features of runners' lifestyle - they are ready to sacrifice pleasant things or experience which can disrupt their preparation to races or endanger their fitness. They exercise (it is an original meaning of the Greek word askésis) both body and will in lifelong horizon. They know running (which is higher level of jogging) is also related to some portion of pain and they are ready to sign a specific runners' motto: "Pain is inevitable. Suffering is optional." If they suffer, such situations open the way to "peak experiences" (Maslow, 1954). Per aspera ad astra!

\section{CONCLUSION}

Promoting "reasonable asceticism" can be one aspect of raison d'être of today's sport in this postmodern world with the supremacy of hedonistic orientation. 


\section{REFERENCES}

Bednář, M. (2011). „Běchovice“: tradice, kult $i$ motivace. Praha: European Science and Art Publishing.

Bednář, M. (2009). Sport, Asceticism and Hedonism. Journal of Outdoor Activities, 2(1), 4-11.

Csikszentmihalyi, M. (1990). Flow: The Psychology of Optimal Experience. New York: Harper Perennial.

Deci, E. L., Koestner, R., \& Ryan, R. M. (1999). The undermining effect is a reality after all: Extrinsic rewards, task interest, and self-determination. Psychological Bulletin, 125, 692-700.

Deci, E. L., \& Ryan, R. M. (1985). Intrinsic motivation and self-determination in human behavior. New York: Plenum Press.

Douillard, J. (1994). Body, Mind, and Sport. New York: Random House.

Edmunds, J., Ntoumanis, N., \& Duda, J. (2006). A test of self-determination theory in the exercise domain. Journal of Applied Social Psychology, 36(9), 22402265.

Received on November 17, 2014

Accepted on December 08, 2014
Gallagher, K. M., \& Updegraff, J. A. (2011). When 'fit' leads to fit, and when 'fit' leads to fat: How message framing and intrinsic vs. extrinsic exercise outcomes interact in promoting physical activity. Psychology \& Health, 26(7), 819-834.

Malinauskas, R., Batutis, O., \& Jetkevičius, D. (2005). Peculiarities of formation of intrinsic and extrinsic motivation of lovers of sports in aerobics. Sporto mokslas, 3(41), 51-54.

Malinauskas, R. (2008). The peculiarities of motivation for sports activity among students playing basketball. Ugdymas. Kūno kultūra. Sportas, 4(71), 57-62.

Maslow, A. (1954). Motivation and personality. New York: Harper.

Murakami, H. (2009). What I talk about when I talk about running. London: Vintage Books.

Overman, S. J. (2011). The Protestant Ethic and the Spirit of Sport: How Calvinism and Capitalism Shaped America's Games. Macon, Georgia: Mercer University Press.
Corresponding author Miloš Bednář Charles University in Prague Severní VI/301, 14100 Praha 41 Czech Republic

E-mailmilbed@volny.cz 